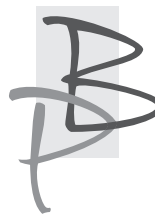

Teresa Rączka-Jeziorska*

Instytut Badań Literackich PAN, Warszawa

https://orcid.org/0000-0003-4857-9480

\title{
„Narodowe serce" Polskich Inflantczyków. Zapis pracy oraz jego diagnostyka w XIX wieku według Józefa i Bolesława Limanowskich
}

Streszczenie: W drugiej połowie XIX wieku stan narodowego ducha, zwłaszcza na ziemiach należących niegdyś do państwa polsko-litewskiego, nie był tematem traktowanym obojętnie. Działo się tak w przypadku mieszkańców dawnych Inflant Polskich, których światli przedstawiciele najczęściej, mimo trudnych warunków życia, wychowywali się na patriotycznych lekturach i wzniosłych ideałach. W prezentowanym artykule zwrócono uwagę na urodzonych w majętności Podgórz nad Dźwiną braci Limanowskich: Józefa, Lucjana oraz Bolesława. Ich głos stał się na tej płaszczyźnie szczególnie wymowny. Z tego też powodu podjęto próbę zbadania wybrzmiewającej w ich głosie romantycznej metaforyki, a przede wszystkim rezonansu, jaki zyskała ona w Łatgalii.

Słowa-klucze: Łotwa, Łatgalia, romantyzm, ojczyzna, patriotyzm.

Teresa Rączka-Jeziorska - adiunkt w Pracowni Literatury Romantyzmu Instytutu Badań Literackich PAN; badaczka literatury romantycznej, wschodniego pogranicza dawnej Rzeczypospolitej i polsko-bałtyckich związków kulturowych. Autorka monografii o rzekach w twórczości Adama Mickiewicza i Tarasa Szewczenki (2011), romantyzmie polsko-inflanckim (2016), pisarstwie Iriny Saburovej (2017), kulturze dworu ziemiańskiego dawnych Inflant Polskich w XIX w. (2018). 


\section{"National Heart" of Polish Inflanty (Livonia). Record of activity and diagnostic examination in the 19th century according to Józef and Bolesław Limanowski}

Summary: In the second half of the $19^{\text {th }}$ century, the condition of the national spirit, especially in the lands that once belonged to the Polish-Lithuanian state, was not a subject that was treated indifferently. This was the case of the inhabitants of the former Polish Livonia, whose enlightened representatives repeatedly, despite difficult living conditions, grew up on patriotic readings and lofty ideals. The article draws attention to the Limanowski brothers born in Podgórze-upon-Daugava: Józef, Lucjan and Bolesław. Their voice became particularly meaningful on this plane. For this reason, an attempt was made to examine romantic metaphors resounding in their voice, and above all the resonance it gained in Latgale.

Key words: Latvia, Latgale, Romanticism, homeland, patriotism.

\section{Reguły ,gry”}

Podobna jest Rzeczpospolita, którą założyć macie, do lasu, który sieje gospodarz. Jeśli gospodarz zasieje nasienie na ziemi dobrej, może być pewny, iż się drzewa urodzą; i nie ma potrzeby myśleć o formie drzew i lękać się, aby się dęby nie urodziły z kolcami, a jodły z liściami. Zasiewajcie więc miłość Ojczyzny i duch poświęcenia się, a bądźcie pewni, iż wyrośnie Rzeczpospolita wielka i piękna ${ }^{1}$.

Józef i Bolesław Limanowscy, przyszli inicjatorzy może jednej z najbardziej wymownych dyskusji o kondycji polskiego narodowego ducha w ,pogranicznej prowincji” nad Dźwiną, toczącej się na łamach paryskiej prasy w drugiej połowie XIX wieku, na symboliczną przypowieść nauczyciela - proroka $^{2}$ z Ksiag pielgrzymstwa polskiego, będąc jeszcze dziećmi, początkowo zdawali się od-

1 A. Mickiewicz, Księgi narodu polskiego i pielgrzymstwa polskiego, [w:] tegoż, Proza artystyczna i pisma krytyczne, opr. Z. Dokurno, Wyd. Rocznicowe, t. 5, Warszawa 1999, s. 54.

2 Por. Z. Stefanowska, Historia i profecja. Studium o ,Księgach narodu i pielgrzymstwa polskiego" Adama Mickiewicza, Warszawa 1962, s. 9, 101, 107, 125-128, 147-157. 
powiadać dość bezwiednie. Ale czy można na tym etapie życia oczekiwać czegoś więcej? Dużą przyjemność chłopcy odnajdywali na przykład w ułożonej i opublikowanej przez Klementynę z Tańskich Hoffmanową w 1829 roku grze Assarmot ${ }^{3}$. Była to gra planszowa ilustrująca dzieje ojczyzny ${ }^{4}$. Jej środek zajmowała mapka Królestwa Polskiego, utworzonego na Kongresie Wiedeńskim, a poszczególne obrazki przedstawiały ważniejsze wydarzenia historyczne. Najgorzej było trafić pionkiem na miejsce symbolizujące ostateczny rozbiór Polski. Wówczas grający płacił nie tylko wielką karę, ale zostawał usunięty z gry.

Do najbardziej ulubionych rozrywek młodych Limanowskich zaliczała się jednak zabawa w tak zwane „trzy rzeczpospolite”. Józef i Bolesław wraz z bratem Lucjanem zakładali je w obrębie rodzinnego majątku Podgórz, leżącego obok Liksny w dawnych Inflantach Polskich, wykorzystując potencjał ogrodu owocowego, dworskich zabudowań i pomieszczeń gospodarskich. Miały one swoje wojsko, mogły zawierać między sobą przymierza albo wspólnie szykować inwazję. Planowali podobno nawet połączyć siły, by wspólnie rozpocząć wojnę z Moskwą. Dziecięcy projekt odłożyli jednak na później.

Przyszłe losy tej trójki, częściowo utrwalone na kartach pamiętników jednego z najbardziej zaangażowanych działaczy narodowej walki o niepodległość, pokazują, że nie skończyło się wyłącznie na rzucie kostką i wyuczonym ruchu pionkiem. Jaką rolę odegrały tutaj domowe strony?

\section{Ziemia Emilii Plater}

To, co było złe i przykre, utonęło w mroku zapomnienia, a z głębi przeszłości wynurzają się miłe obrazy, wzbudzające żywe bicie serca ${ }^{5}$ i tkliwą rzewność. Piękny to kąt kraju 6 .

Z dziejami Limanowskich w dzisiejszej Łatgalii na Łotwie związana jest polsko-inflancka rodzina Platerów. Stało się to za sprawą miejsca, w którym

3 S. Gawlik, Dziedzictwo pedagogiczne Klementyny z Tańskich Hoffmanowej, Opole 1995, s. 57. Zob. reprodukcję mapy wraz z komentarzem [w:] D. Siwicka, Mapy romantyków, Warszawa 2018, s. 124-127.

4 Dalej objaśniam za: B. Limanowski, Pamiętniki (1835-1870), Warszawa 1957, s. 40.

5 Wszystkie pogrubienia w tym cytacie oraz kolejnych pochodzą od autorki.

6 B. Limanowski, Pamiętniki (1835-1870), s. 24. 
najpewniej przyszli na świat synowie Wincentego [1771-1847] i Katarzyny z Wysłouchów [1807-1892]. Na mocy plenipotencji udzielonej 18 listopada 1822 roku przez hrabiego Konstantego Platera (syna Kazimierza Konstantego Platera), występującego także w imieniu swego rodzeństwa, Wincenty Limanowski, były asesor powiatu dyneburskiego, nabył od Michała Niemczyńskiego, porucznika wojsk polskich, majętność w Podgórzu, położoną na terenie powiatu dyneburskiego w okolicy ujścia rzeczki Indry do Dźwiny. Intromisja Wincentego Limanowskiego do tego majątku nastąpiła 4 sierpnia 1824 roku.

Z dobrami podgórskimi, w których wychowywali się później bracia Limanowscy, a w początkach XIX wieku należącymi do kilku właścicieli (między innymi potomków Kazimierza Konstantego Platera oraz rodziny Mohlów), łączą się jednak przede wszystkim losy słynnej bohaterki powstania listopadowego, Emilii Plater ${ }^{7}$. Część tych ziem, będąca w posiadaniu Dionizego von der Mohla, sędzica inflanckiego, znalazła się w 1824 roku jako zastaw w rękach matki młodej Platerówny, Anny z Mohlów, a po jej śmierci prawa do nich przeszły na Emilię. Hrabianka wprawdzie nie mieszkała w Podgórzu, ale formalnie czerpała dochody z tej części majątku, której pozostawała spadkobierczynią.

Choć z czasów platerowskich Bolesławowi udało się jedynie zapamiętać nazwę folwarku niegdyś znajdującego się przy rzeczce („Odpoczynek”), który ojciec przeniósł bliżej Indrycy, to aura tego miejsca wywierała wpływ na całe dorosłe życie chłopców. Niejednokrotnie dawali temu wyraz na kartach wspólnej korespondencji:

Nieraz myśl wybiega do przeszłości, biegnie do Podgórza, Kozłowa, Warnowicz... ale złamana ubiegłem życiem, wszystkiem co się stało, [...] z podciętemi skrzydłami wraca i nie może rozjaśnić się dawną radością?

7 O szczegółach tych związków zob. T. Rączka-Jeziorska, Inflanckie pitoreski. Kultura dworu ziemiańskiego dawnych Inflant Polskich w XIX wieku, Warszawa 2018, s. 345-348. Por. M. Śliwa, B. Limanowski. Człowiek $i$ historia, Kraków 1994, s. 9.

8 Rkps BN, sygn. 2900 II [Korespondencja Lucjana i Józefa Limanowskich z lat 1864 1877] k. 26. 
Byłem w różowem usposobieniu, zagarnąwszy inflanckiego powietrza i przekonawszy się na wstępie, że pomimo wrzasku toczy się życie po staremu w tym samym korycie?.

Tworzyło ją nie tylko malownicze otoczenie posiadłości, usytuowanej na niewielkim wzniesieniu wśród lasów, łąk, jezior i strumieni, ale przede wszystkim pielęgnowana w podgórskim dworze obyczajowość. Mimo iż skromne dochody rodziców nie zapewniały wystawnego stołu ani wyszukanych rozrywek, Limanowscy, będąc częścią jednej polsko-inflanckiej społeczności, dzielili codzienność innych rodzin ziemiańskich. Uczestniczyli więc we wspólnych balach, kiermaszach, zabawach. Razem z sąsiadami obchodzili imieniny i świętowali uroczystości kościelne. Nie unikali także, zwłaszcza Bolesław, przyjaznych kontaktów ze służbą, jakkolwiek ojciec, podżegany przez wójta by stosować względem swych poddanych system kar, nie dawał im zbyt dobrego przykładu. W domu starano się również należycie zadbać o ich edukację. W dzieciństwie wraz z pozostałym rodzeństwem otoczeni byli troskliwą opieką łotewskiej piastunki, której bajkowe historie twórczo oddziaływały na wyobraźnię. Pobierali także nauki od zagranicznych guwernerów, odpowiedzialnych między innymi za naukę języków. Aczkolwiek nie oni rozniecali w nich patriotyczne uczucia:

Zapewne sama atmosfera rodzinna i społeczna, którą oddychaliśmy duchowo, czyniła nas Polakami. [...] Mówiąc o patriotyzmie mam na myśli nie bierny, lecz czynny patriotyzm, tę rozżarzającą się coraz silniej chęć pomszczenia krzywd narodowych, wyrzucenia wrogów z granic swych ziem. Wpływ rodziców był żaden. Najprzód, mało się zajmowali nami; a po wtóre, panowanie rosyjskie nie wzbudzało w nich uczucia buntu ${ }^{10}$.

Zatroszczyli się o to starsi bracia, Aleksander i Anicenty. Nauczyli ich rozumieć Lelewela i Niemcewicza, a swymi opowieściami, zwłaszcza o represjach towarzyszących powstaniu 1830/1831 roku, prowokowali do samodzielnych lektur:

10 B. Limanowski, Pamiętniki (1835-1870), s. 38. 
Mnie zachwycał Zawisza Czarny, z gorącym też uczuciem deklamowałem wiersze Karpińskiego. Umiałem na pamięć Alpuharę Mickiewicza. W ogóle mściciele krzywd, a nade wszystko mściciele krzywd narodowych wzbudzali zachwyt, uwielbienie ku sobie ${ }^{11}$.

Bolesław Limanowski krótką modlitwę w intencji ojczyzny z Pielgrzyma w Dobromilu ${ }^{12}$, którą potrafił recytować z pamięci, uzupełniał prośbą o zniesienie poddaństwa. Wkrótce też odkrył znaczenie legendarnej hagiografii, budowanej wokół postaci Emilii Plater ${ }^{13}$. Wychowany w tych samych okolicach z pewnością rozumiał jej romantyczne przesłanie lepiej niż ktokolwiek inny. Spod jego ręki w 1861 roku ${ }^{14}$ wyszła pierwsza rzetelna ${ }^{15}$ biografia Platerówny oparta na gruntownej kwerendzie w Bibliotece Polskiej w Paryżu ${ }^{16}$. Co ciekawe, Limanowski publikował ją wpierw w odcinkach na łamach lwowskiego „Dziennika Literackiego” (nr 25-27), posługując się pseudonimem inflanckiego włościanina Janka Płakania ${ }^{17}$, a dopiero kilkadziesiąt lat później przeredagował i wydał pod swoim nazwiskiem na łamach „Biblioteki Warszawskiej”18.

11 Tamże, s. 39.

12 Por. symboliczne słowa tego wezwania: „Boże nieograniczony w swej dobroci! który nie odrzucasz prośby szczerej i pokornej, nie opuszczaj Polski i Polaków. Prowadź ich łaską Twoją do cnoty, a zatem do szczęścia. Błogosław ojczyznę naszę, niech będzie szczęśliwą. A jeżeli odważamy się Ciebie, o Boże! prosić za nią, toś sam nas nauczył, że będąc Ojcem naszym, możemy jako dzieci Twoje polecać Tobie to, co w życiu najdroższego mamy". I. Czartoryska, Nauka dwudziesta druga, [w:] tejże, Pielgrzym w Dobromilu, czyli nauki wiejskie, Warszawa 1820, s. 198.

13 Por. K. Zajas, Nieobecna kultura. Przypadek Inflant Polskich, Kraków 2008, s. 148-149; T. Rączka-Jeziorska, Romantyzm polsko-inflancki. Sylwetki, teksty, archiwa, Warszawa 2016, s. 217-224; М. Виткунас, Эмилия Плятер в исторической памяти литовцев, „Vēsture: avoti un cilvēki”, XXI, Daugavpils 2018, s. 405-415.

14 Bolesław Limanowski wspominał o tej publikacji dopiero kilka lat później w liście do Lucjana i Józefa Limanowskich z 11 marca 1868 roku: „Pierwszy raz wczoraj przeczytałem w druku życiorys Emillii - przez Płakania”. Rkps BN, sygn. 2900 II, k. 24.

15 D. Samborska-Kukuć, Inflanty Polskie Bolesława Limanowskiego - wspomnienia i relacje, „Acta Universitatis Lodziensis, Folia Litteraria Polonica” 2013, nr 4 (22), s. 81.

16 M. Śliwa, B. Limanowski, s. 24.

17 Tamże, s. 25,

18 Zob. B. Limanowski, Emilia Plater. Szkic biograficzny, „Biblioteka Warszawska” lipiec 1910, t. 3, z. 1, s. 331-351 oraz wyd. następne: Emilia Platerówna, [w:] tegoż, Szermierze wolności, Kraków 1911, s. 1-26. 
Do bliższego zapoznania się z życiorysem walecznej „dziewicy” zachęciła go także dorpacka znajomość z utalentowanym szachistą, Michałem Platerem $\mathrm{z}$ Kombula ${ }^{19}$. Kontakt z nim okazał się jednak ważny jeszcze z innego powodu. Kolega ze studiów, będąc synem Józefa Kazimierza Platera [1796-1852], czynnego literata, współpracownika Rubonu, autora między innymi Rocznika gospodarskiego, a także bratem Celiny Plater [1839-1864], zbieraczki polskoinflanckiego folkloru, oraz Leona Platera [ur. 1836], zgładzonego w 1863 roku za udział w powstaniu, zaimponował mu nie tylko patriotyczną postawą, ale też wtajemniczył w działalność emigracji polskiej w Paryżu:

Pobyt w Kombulu nie minął bez pozostawienia swego wpływu. Michał, odprowadzając mnie do pokoju przeznaczonego na nocleg, dał mi do przeczytania kilka numerów „Wiadomości Polskich”20, wydawanych w Paryżu, i broszurkę Klaczki z powodu przemówienia Mierosławskiego na obchodzie listopadowym. Przeczytałem je z wielką ciekawością. „Wiadomości Polskie” i pięknym swym stylem, i treścią ujęły mnie i po przyjeździe do Dorpatu skłoniłem Ogół nasz do zaprenumerowania tego pisma przez pośrednictwo miejscowego księgarza, z którym rozmówiłem się w tej sprawie. $W$ ten sposób weszliśmy w pewien kontakt z emigracją, zaczęły do nas dochodzić wieści, co się tam działo i co zamierzano robićc1.

Realną możliwość publikacji na łamach narodowego pisma, wydawanego we Francji, a przede wszystkim wypowiedzenia się w sprawach inflanckich, dał mu jednak starszy brat Józef22, który pod koniec kwietnia 1860 roku w „Przeglądzie Rzeczy Polskich” ogłosił entuzjastyczny szkic ${ }^{23}$ na temat

19 Michał Hieronim Plater (1834-1924), syn Józefa Kazimierza, dziedzica dóbr Kombul, Kazanowa oraz współwłaściciela miasteczka Borówka w powiecie dyneburskim. Zob. Sz. Konarski, Platerowie (Materiały do biografii, genealogii i heraldyki polskiej. Źródła i opracowania, t. 4), Buenos Aires 1967, s. 115-116.

20 Por. M. P. Gancewski, Polskie życie narodowe w kraju w latach 1857-1861 w ocenie «Wiadomości Polskich» (część I), „Prace Historyczne” 2015, nr 142, z. 1, s. 113-134.

21 B. Limanowski, Pamiętniki (1835-1870), s. 206.

22 M. Śliwa, B. Limanowski, s. 26.

23 J. Limanowski, Stan polskiej narodowości w Inflantach (Korespondencya nadestana z Inflant, 20 grudnia 1859), „Przegląd Rzeczy Polskich”, z. 4, dn. 29 kwietnia 1860, s. 13-38. Treść tego artykułu opublikowałam w postaci aneksu źródłowego na kartach swojej monografii pt. Inflanckie pitoreski. Kultura dworu ziemiańskiego dawnych Inflant Polskich w XIX wieku, s. 41-60. 
mieszkańców nadźwińskiej prowincji, nobilitujący ich kulturę i obyczajowość. Według Juliusza Bardacha Bolesław ${ }^{24}$ poszedł jednak o krok dalej i uściślił te kwestie, które w artykule Józefa zostały pominięte lub przedstawione w sposób zacierający istniejące różnice społeczne i konflikty25:

W odróżnieniu od Józefa, który przedstawiał szlachtę jako całość, Bolesław wyodrębniał arystokrację, do której należą „familie pochodzące od dawnych mieczowych rycerzy, jak również i pewna ilość rodzin nie mająca podobnych antenatów". Arystokraci ci (mowa o rodach inflanckich) mimo wykształcenia i innych przymiotów „dobrowolnie wyrzekają się moralnego przewodniczenia reszcie szlachty, zasklepiając się tylko w ciasnym kółku, odstręczając i oburzając wszystkich swą dumą -, zacieśniają swój patriotyzm w wąskich obrębach konserwatyzmu: ograniczają go na przechowaniu uczucia polskiego, na przywiązaniu do religii, na przestrzeganiu pilnym podań rodzinnych". Trudno od nich spodziewać się otwartego wystąpienia wobec zaborcy - sądził B. Limanowski²6.

Dorota Samborska-Kukuć dopowiada, iż miejscowej elicie wytknął zwłaszcza bierną postawę i utajoną zachowawczość:

Z naciskiem podkreśla Limanowski stan świadomości politycznej szlachty inflanckiej z okresu przedednia powstania styczniowego. Podkreśla obawy szlachty o wprowadzenie uwłaszczenia, ubolewa nad lękliwością, ostrożnością i taktyką dyplomatycznego lawirowania starej generacji, bojącej się jak ognia jakiegokolwiek ruchu, który mógłby wzbudzić podejrzenie Rosji27.

Oba teksty Limanowskich, wydrukowane pod redakcją Seweryna Elżanowskiego ${ }^{28} \mathrm{w}$ odstępie zaledwie kilku miesięcy, pomimo tych odrębnych

24 Zob. B. Limanowski, Korespondencja z Inflant, „Przegląd Rzeczy Polskich”, z. 17, dn. 15 grudnia 1860 .

25 J. Bardach, Inflanty, Litwa, Białoruś w twórczości Bolesława Limanowskiego: studium $z$ dziejów w kwestii narodowej, „Przegląd Historyczny” 1974, 65/3, s. 482.

26 Tamże.

27 D. Samborska-Kukuć, Inflanty Polskie Bolestawa Limanowskiego, s. 83.

28 Władysław Mickiewicz podaje, że założony w 1857 r. przez Seweryna Elżanowskiego „Przegląd Rzeczy Polskich” został zawieszony przez rząd francuski 17 stycznia 1863 r. Zob. tenże, Emigracya polska 1860-1890, Kraków 1908, s. 145. 
stanowisk względem szlacheckiej społeczności stały się niewątpliwie formą promocji polsko-inflanckiego regionu za granicą, lecz przede wszystkim dobitną manifestacją zadeklarowanego już w dzieciństwie lokalnego patriotyzmu. Zwłaszcza ze strony Józefa, który w opinii Bolesława miał spośród tej trójki, zarówno w charakterze, jak i w pomysłach, zdecydowanie najwięcej „fantastyczności”28.

\section{Spod znaku serca}

Jednakże tym razem, szczególnie w sposobie formułowania sądów, udzieliła mu się dość wyraziście lekarska retoryka brata Lucjana, który kształcił się przez pewien czas w warszawskiej Akademii Medyczno-Chirurgicznej, założonej w 1857 roku. Kluczowym fragmentem publikacji Józefa Limanowskiego wydaje się bowiem precyzyjna diagnoza uczuciowości Polskich Inflantczyków. Ilustruje ją następujący „kardiogram”:

Bicie Inflanckiego serca do r. 1831 było niepewne i lubo szlachta świeższy, niż teraz, polski przechowywała koloryt, jednak rzecz niezawodna, iż rząd moskiewski, potęgując oświatę i swobodę w tym kraju, mógłby go sobie zjednać i bicie serca zsympatyzować ku sobie. Samo już bowiem zostawienie status quo w Inflantach było przyczyną, iż ta prowincja w r. 1831 marginesowy wykazała charakter. Atoli od r. 1831 nastąpiła kryzys sercowa i do bliższego ogniska miłości ojczyzny obficie nowego dorzuciła paliwa. Od tego czasu moskiewska polityka w wielu miejscach zdemontowaną, w wielu na zawsze zagwożdżoną została ${ }^{29}$.

Limanowski uwzględnił $\mathrm{w}$ nim przede wszystkim przełomowe również dla Łatgalii wydarzenia 1830/1831 roku $^{30}$. Oceniając postawę jej mieszkańców wobec Rosji po powstaniu listopadowym podkreślił, że Rosjanie zaprzepaścili swoją szansę pokojowej asymilacji dawnego województwa inflanckiego. Zachowanie dotychczasowych porządków prawnych i administracyjnych

28 B. Limanowski, Pamiętniki (1835-1870), s. 152.

29 J. Limanowski, Stan polskiej narodowości w Inflantach, s. 29.

30 O odbiorze powstania listopadowego wśród szlachty polsko-inflanckiej zob. H. Strods, Odgłosy powstania listopadowego na Łotwie, "Zapiski Historyczne” 1981, t. XLVI, z. 3, s. 33-75. 
na tym terenie (statut litewski, liczne organy samorządu szlacheckiego znane z „czasów polskich”, język polski w administracji) spowodowało, że szlachta polsko-inflancka nie wzięła w nim udziału (poza pojedynczymi przykładami - na przykład związanych z Inflantami Polskimi, Emilią z Broel-Platerów ${ }^{31}$ [1806-1831] czy generałem Janem Weyssenhoffem [1774-1848]). Z drugiej zaś strony zwrócił uwagę, że błędem ze strony Rosjan było zarzucenie reform szkolnictwa, które pozostawiono w stanie stagnacji wywołanej przez jezuitów, jak również próby ograniczania swobód obywatelskich, do których przyzwyczajona była społeczność szlachecka dawnych Inflant Polskich. W jego przekonaniu to wszystko, plus, być może w największym stopniu, dojrzewający na prowincji romantyzm, przyczyniło się do „kryzysu sercowego”, czyli ponownego zapałania miłością do tradycji dawnej Rzeczypospolitej i ogólnie pojętej polskości:

Z tego wszystkiego, com tu powiedział, jasno daje się widzieć, iż Inflanty zostawione samym sobie lub miłości moskiewskiej, długo jeszcze by wiodły ciężki barbarzyństwa żywot. Atoli niebieska światłość, przypływająca ku nam z ojczystej Polski, rozprasza mroki polarne, zapewniając błogą w przyszłości pomyślność. Zbawienny wpływ powoli przenika narodowe serce, napawa go duchem polskości i skłania do żywszych manifestacyj swych uczuć ${ }^{32}$.

Pozytywnych skutków wznowionej dzięki listopadowemu zrywowi ,akcji serca", która objęła przeważającą część państwa polsko-litewskiego dopatrywała się, za jednym z jego uczestników, Maria Janion:

"Serce" musiało się więc pojawić w sposób konieczny - oto decydująca motywacja romantycznego czynu. „Miej serce i patrzaj w serce”, przez cały wiek pamiętano wskazanie z wiersza programowego pt. Romantyczność. Ale nawet trzeźwy liberał, Karol Boromeusz Hoffmann, opisując wybuch i pierwsze dni powstania listopadowego, nie mógł się powstrzymać od romantycznej retoryki: „Skutek pokazał, że Rewolucja, acz nie we wszystkich głowach, była przecież we

31 O charakterze związków Emilii Plater z Łatgalią zob. T. Rączka-Jeziorska, Romantyzm polsko-inflancki. Sylwetki, teksty, archiwa, Warszawa 2016, s. 216-237.

32 J. Limanowski, Stan polskiej narodowości w Inflantach, s. 38. 
wszystkich sercach", trzeba było tylko śmiałego głosu [podchorążych], żeby we wszystkich sercach rozniecić święty ogień koniecznej obrony", i wreszcie tak wyglądała gwarancja triumfu: „Ulitował się Bóg nad sprawą uciśnionych”, i co było we wszystkich sercach, udać się musiało. Dnia 30 listopada około godziny 8-mej rano powitaliśmy "jutrzenkę oswobodzenia Polski"32.

Ale to w Polskich Inflantach właśnie, chyba najdonośniej na północno-wschodnich rubieżach (ziemiach przyłączonych w 1772 do Rosji w ramach I rozbioru), dały się słyszeć głosy tego poruszenia. Obudzonej z letargu szlachcie, której „serce”, jak w przypadku Kazimierza Bujnickiego, biło przedtem z równą mocą także dla cesarza Aleksandra I ${ }^{33}$, po 1830/1831 roku zaczęły dotkliwie doskwierać polityczno-administracyjne regulacje. Aczkolwiek, jak trafnie zauważył duszpasterz tych terenów, ks. Józef Borodzicz, „silne napięcie nerwów patriotycznych"34 wystąpiło dopiero około 1863 roku. Pomnikowym bohaterem tych dni stał się tragicznie rozstrzelany 28 maja w dyneburskiej twierdzy Leon Plater ${ }^{35}$, którego imię utrwaliła autorka Dramatu bez nazwy, a także kolejne pokolenia. O tym, że był w Łatgalii sprawcą prawdziwie romantycznego „czynu”, świadczyły też wówczas najświeższe prasowe doniesienia:

W Dynaburgu rozstrzelano znowu bardzo wielkiego pana, hrabiego Leona Platera; o śmierci jego piszą, że gdy go Moskale rozstrzelali, więc cały tamtejszy naród i przyjaciele, co go kochali bardzo, płakali rzewliwie, co widząc matka jego

32 M. Janion, Artysta romantyczny wobec narodowego sacrum, [w:] tejże, Prace wybrane, t. 4: Romantyzm i jego media, Kraków 2001, s. 215. „Serce to hasło zamykające w sobie wszystkie wartości romantyczne. Listopadowe hasło «do broni» wskazuje, że dawna wielka tradycja rycerska odżyła zmów w romantycznym pokoleniu bohaterów nocy belwederskiej". J. Kamionka-Straszakowa, Nasz naród jak lawa. Studia z literatury i obyczaju doby romantyzmu, Warszawa 1974, s. 196.

33 Por. K. Bujnicki, Pamiętniki (1795-1875), oprac. P. Bukowiec, Kraków 2001, s. 20-23.

34 Kartka z dziejów Inflant Polskich. Z pamiętników ks. Józefa Borodzicza, Chrzanów 1911, s. 12.

35 Więcej o wydarzeniach 1863 r. zob. D. Samborska-Kukuć, Leona Platera droga do bohaterstwa. Z dziejów powstania styczniowego za Dźwina, „Prace Naukowe Akademii im. Jana Długosza w Częstochowie" 2013, z. 13, s. 23-33; tejże, Wydarzenia 1863 roku w Inflantach Polskich w relacjach $i$ wspomnieniach, „Zapiski Historyczne” 2008, z. 4, s. 133-144. 
staruszka rzekła: „Nie płaczcie, widzicie, ja nie płaczę; płakałabym, gdyby mój syn był się zląkł wyroku moskiewskiego; byłam dziś u niego w więzieniu, pobłogosławiłam go, modliłam się z nim i za nim". To mi dopiero matka pobożna, prawdziwa Polka! ${ }^{36}$

Jego symboliczna ofiara zdynamizowała później ogólnonarodową ,akcję serca". Angażował się w nią spektakularnie, właściwie do końca swych dni Bolesław Limanowski, któremu nad Dźwinę nie dane już było nigdy więcej na dobre powrócić:

Ściskało mi się serce na samą myśl, że w tych kątach, gdzie się najpiękniej i najżwawszy serce uderzało, obcym zostać wypadnie ${ }^{37}$.

\section{Epikryza}

Rzeczpospolita, której rozmiary, kształt i granice projektowali w swych dziecięco-młodzieńczych wizjach bracia Limanowscy, przeszło półwiecze później nie objęła już wprawdzie obszarów ukochanego Naddźwinia. Romantyczny ideał wymarzonej wolności długo jednak aktywizował na tych terenach kolejne, zresztą nie tylko polsko-inflanckie ,serca”. Zniknęła też w końcu obawa przed wyrzuceniem kostką do gry niepożądanej liczby oczek.

36 Cytuję za „Nowiny ze świata”, Kraków, 1 lipca 1863, nr 7, R. I, s. 6. Por. „Praca”, Lwów, 25 czerwca 1863, nr 8, R. I, s. 58.

37 Rkps BN, sygn. 2900 II, k. 40v. 


\section{Bibliografia}

\section{Źródła archiwalne}

Rkps BN, sygn. 2900 II [Korespondencja Lucjana i Józefa Limanowskich z lat 18641877].

\section{Źródła drukowane}

Bujnicki K., Pamiętniki (1795-1875), oprac. P. Bukowiec, Kraków 2001.

Czartoryska I., Nauka dwudziesta druga, [w:] tejże, Pielgrzym w Dobromilu, czyli nauki wiejskie, Warszawa 1820.

Kartka z dziejów Inflant Polskich. Z pamiętników ks. Józefa Borodzicza, Chrzanów 1911.

Limanowski B., Emilia Plater. Szkic biograficzny, „Biblioteka Warszawska” lipiec 1910, t. 3, z. 1.

Limanowski B., Korespondencja z Inflant, „Przegląd Rzeczy Polskich”, z. 17, dn. 15 grudnia 1860.

Limanowski B., Pamiętniki (1835-1870), Warszawa 1957.

Limanowski J., Stan polskiej narodowości w Inflantach (Korespondencya nadesłana z Inflant, 20 grudnia 1859), „Przegląd Rzeczy Polskich”, z. 4, dn. 29 kwietnia 1860.

Limanowski B., Szermierze wolności, Kraków 1911.

Mickiewicz A., Księgi pielgrzymstwa polskiego, [w:] tegoż, Proza artystyczna i pisma krytyczne, opr. Z. Dokurno, Wyd. Rocznicowe, t. 5, Warszawa 1999.

„Nowiny ze świata”, Kraków, 1 lipca 1863, nr 7, R. I.

„Praca”, Lwów, 25 czerwca 1863, nr 8, R. I.

\section{Literatura przedmiotowa}

Bardach J., Inflanty, Litwa, Białoruś w twórczości Bolesława Limanowskiego: studium z dziejów w kwestii narodowej, „Przegląd Historyczny” 65/3, 1974.

Witkunas M., Emilija Platier w istoriczeskoj pamiati litowcew, „Vēsture: avoti un cilvēki", XXI, Daugavpils 2018.

Gancewski M. P., Polskie życie narodowe w kraju w latach 1857-1861 w ocenie «Wiadomości Polskich» (część I), „Prace Historyczne” 2015, nr 142, z. 1.

Gawlik S., Dziedzictwo pedagogiczne Klementyny z Tańskich Hoffmanowej, Opole 1995. 
Janion M., Artysta romantyczny wobec narodowego sacrum, [w:] tejże, Prace wybrane, t. 4: Romantyzm i jego media, Kraków 2001.

Kamionka-Straszakowa J., Nasz naród jak lawa. Studia z literatury i obyczaju doby romantyzmu, Warszawa 1974.

Konarski Sz., Platerowie (Materiały do biografii, genealogii i heraldyki polskiej. Źródła i opracowania, t. 4), Buenos Aires 1967.

Mickiewicz W., Emigracya polska 1860-1890, Kraków 1908.

Rączka-Jeziorska T., Inflanckie pitoreski. Kultura dworu ziemiańskiego dawnych Inflant Polskich w XIX wieku, Warszawa 2018.

Rączka-Jeziorska T., Romantyzm polsko-inflancki. Sylwetki, teksty, archiwa, Warszawa 2016.

Samborska-Kukuć D., Inflanty Polskie Bolesława Limanowskiego - wspomnienia i relacje, „Acta Universitatis Lodziensis, Folia Litteraria Polonica” 2013, nr 4 (22).

Samborska-Kukuć D., Leona Platera droga do bohaterstwa. Z dziejów powstania styczniowego za Dźwiną, „Prace Naukowe Akademii im. Jana Długosza w Częstochowie" 2013, z. 13.

Samborska-Kukuć D., Wydarzenia 1863 roku w Inflantach Polskich w relacjach i wspomnieniach, „Zapiski Historyczne” 2008, z. 4.

Siwicka D., Mapy romantyków, Warszawa 2018.

Stefanowska Z., Historia i profecja. Studium o „Księgach narodu i pielgrzymstwa polskiego" Adama Mickiewicza, Warszawa 1962.

Strods H., Odgłosy powstania listopadowego na Łotwie, „Zapiski Historyczne” 1981, t. XLVI, z. 3.

Śliwa M., B. Limanowski. Człowiek i historia, Kraków 1994.

Zajas K., Nieobecna kultura. Przypadek Inflant Polskich, Kraków 2008. 